\title{
ДЕФІЦИТ ВІТАМІНУ D У НАСЕЛЕННЯ УКРАЇНИ ТА ЧИННИКИ РИЗИКУ ЙОГО РОЗВИТКУ
}

B організм людини вітамін D потрапляє у формі ерго- чи холекальциферолу. Ергокальциферол - найпоширеніша природна форма вітаміну D, він утворюється в рослинах з ергостеролу під дією сонячного світла. В організм людини ергокальциферол надходить у відносно невеликих кількостях - не більш ніж 2030\% від потреб. Основними джерелами його поповнення є продукти зі злакових рослин [1].

Холекальциферол утворюється в організмі хребетних тварин, у тому числі амфібій, рептилій, птахів і ссавців, у зв'язку з чим відіграє більш вагому роль у процесах життєдіяльності людини, аніж ергокальциферол, який надходить з їжею. Вітамін D, утворюється в дермальному шарі шкіри з попередника провітаміну $D_{3}$ - 7-дегідрохолестеролу - під впливом короткохвильового ультрафіолетового опромінення спектра В (довжина хвилі 290-315 нм) у результаті фотохімічної реакції розкриття кільця стероїдного ядра і термоізомеризації, характерної для секостероїдів [2]. Саме холекальциферол розглядають як дійсний або істинний вітамін D, тоді як інші представники цієї групи вважаються модифікованими похідними вітаміну D [3].

Вітамін D, який надходить з їжею або утворюється в організмі в процесі ендогенного синтезу, в результаті двох послідовних реакцій гідроксилювання біологічно малоактивних прегормональних форм перетворюється на активні гормональні сполуки: найбільш важливу, якісно і кількісно значущу - 1,25-дигідроксивітамін D (1,25(OH), D), так званий D-гормон (кальцитріол) і мінорну - 24,25(OH) 2 D [2, 4, 5].

Рівень утворення D-гормону в організмі дорослої здорової людини складає близько 0,3-1,0 мкг/добу. Перша реакція гідроксилювання здійснюється переважно в печінці (до 90\%) за участю мікросомального ферменту 25-гідроксилази з утворенням проміжної біологічно малоактивної транспортної форми - 25(OH) вітаміну D або (кальцидіолу) [6, 7].

Гідроксилювання вітаміну D в печінці здійснюється без будь-яких позапечінкових регуляторних впливів і $\epsilon$ повністю субстратзалежним процесом [8]. Реакція 25-гідроксилювання відбувається досить швидко і призводить до підвищення рівня 25(OH) вітаміну D $(25(\mathrm{OH}) \mathrm{D})$ в сироватці крові. Його рівень відображає як утворення вітаміну D у шкірі, так і надходження з їжею, у зв'язку з чим він може використовуватися як маркер концентрації вітаміну D в сироватці крові $[3,9]$. Частково транспортна форма 25(OH)D, яка надходить в жирову і м'язову тканини, може створювати тканинні депо 3 невизначеним терміном існування (рис. 1).

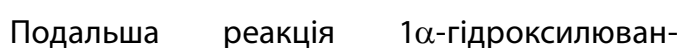
ня 25(OH)D перебігає переважно в клітинах проксимальних відділів канальців кори нирок за участю ферменту 1 $\alpha$-гідроксилази (25-гідроксивітамін D-1 $\alpha$-гідроксилаза, CYP27B1). У значно меншому, ніж у нирках, обсязі 1а-гідроксилювання здійснюється і клітинами лімфогемопоетичної системи, в кістковій тканині i, як встановлено останнім часом, клітинами деяких інших тканин, що містять як 25(OH)D, так

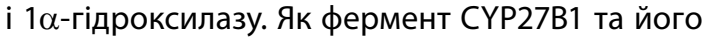
інші ізоформи, так і $1 \alpha$-гідроксилаза $\epsilon$ класичними мітохондріальними і мікросомальними оксидазами зі змішаними функціями, які беруть участь у перенесенні електронів від нікотинамідаденіндинуклеотидфосфату через флавопротеїни і ферродоксин у цитохром $\mathrm{P}_{450}$ [3-4].

$1,25(\mathrm{OH})_{2} \mathrm{D}$ взаємодіє 3 ядерними рецепторами вітаміну D (RVD) тонкого кишечника, нирок та інших тканин. 1,25(OH), D посилює абсорбцію кальцію в тонкому кишечнику завдяки взаємодії із специфічними рецепторами вітаміну D (RVD) та утворює рецепторний комплекс ретинової кислоти, що призводить до експресії в кишковому епітелії кальцієвих каналів (рис. 1).

У ентероцитах активація RVD супроводжується анаболічним ефектом - підвищенням синтезу кальбіндину 9К - кальційзв'язуючого білка, який виділяється в просвіт кишечника, зв'язує $\mathrm{Ca}^{2+}$ i транспортує його через кишкову стінку в лімфатичні судини, а потім у кровоносну систему [8-10]. Про ефективність цього механізму свідчить той факт, що без участі вітаміну D лише 10-15\% кальцію і 60\% фосфору абсорбуються в кишечнику. Взаємодія між 1,25(OH), D та RVD підвищує ефективність кишкової абсорбції $\mathrm{Ca}^{2+}$ до 30-40\%, а фосфору - до 80\% [11, 12]. Подібні механізми дії D-гормону лежать в основі реабсорбції Ca ${ }^{2+}$ у нирках [13] (рис. 1).

1,25(OH) 2 D взаємодіє з рецептором вітаміну D в остеобластах, стимулюючи експресію ліганду рецептора-активатора ядерного фактора каппа B (NF кB), який, у свою чергу, взаємодіє 3 рецептором-активатором NF кB, індукуючи трансформацію незрілих моноцитів у зрілі остеокласти, які розчиняють матрикс і мобілізують кальцій та інші мінерали з кісткової тканини [9].

Утворення в нирках 1,25(OH), D суворо регулюється низкою ендогенних і екзогенних чинників. Зокрема, регуляція синтезу 1,25(OH), D в нирках $\epsilon$ безпосередньою функцією паратиреоїдного гормону (ПТГ), на концентрацію якого в крові, у свою чергу, за механізмом зворотного зв'язку, впливають як рівень самого активного метаболіту вітаміну D, так і концентрація кальцію і фосфору в плазмі крові. Крім того, активу-

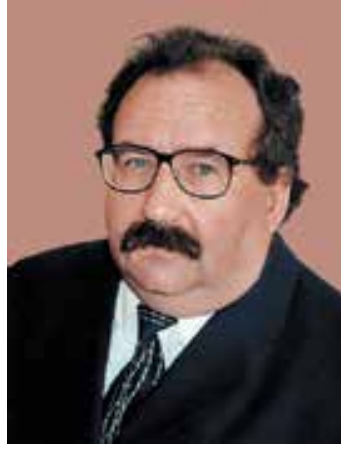

В.В. ПОВОРОЗНЮК

д. мед. н., професор, керівник відділу клінічної фізіології та патології опорно-рухового апарату, ДУ «Інститут геронтології імені Д.Ф. Чеботарьова

НАМН України», Український науково-медичний центр проблем остеопорозу

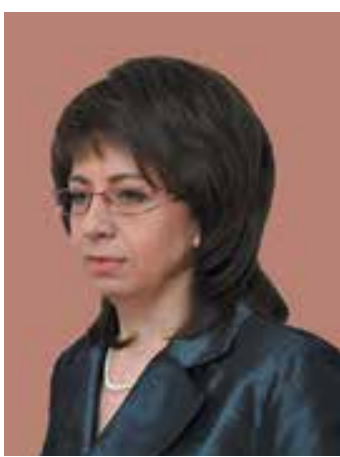

Н.І. БАЛАЦЬКА д. мед. н., провідний науковий співробітник відділу клінічної фізіології та патології

опрно-рухового апарату ду «Інститут геронтології імені Д.Ф. Чеботарьова НАМН України» 


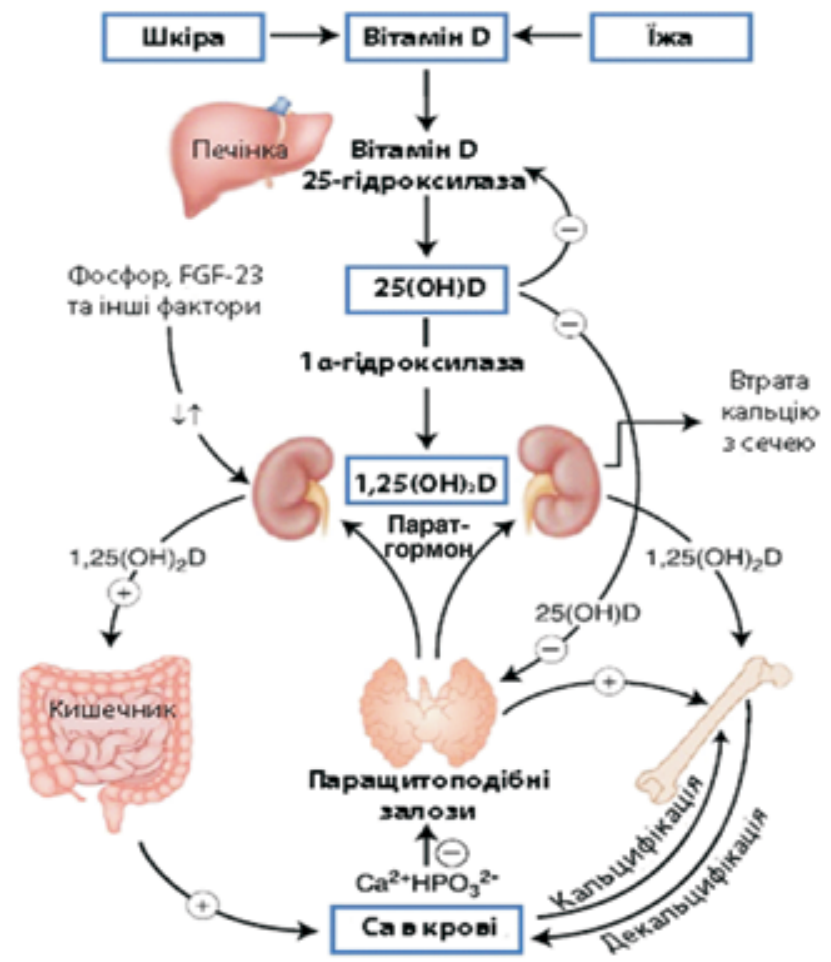

Низький рівень іонізованого кальцію посилює секрецію паратиреоїдного гормону паращитоподібними залозами. У свою чергу, паратиреоїдний гормон збільшує синтез 1,25(ОН) 2D, стимулює абсорбцію кальцію з кишечника, а також мобілізує кальцій з кісткового депо

РИС. 1

СХЕМА ГІДРОКСИЛЮВАННЯ ВІТАМІНУ D ТА ЙОГО ВПЛИВ НА КАЛЬЦІЙФОСФОРНИЙ ГОМЕОСТАЗ (АДАПТОВАНО ЗА WIMALAWANSAS J., 2012)

ючий вплив на $1 \alpha$-гідроксилазу і процес $1 \alpha$-гідроксилювання мають й інші чинники, зокрема статеві гормони (естрогени та андрогени), кальцитонін, пролактин, гормон росту (через інсулінподібний чинник росту 1 ) та інші. Інгібіторами $1 \alpha-$-гідроксилази $\epsilon 1,25(\mathrm{OH})_{2}$ D і низка його синтетичних аналогів, 30крема глюкокортикостероїди, фактор росту фібробластів, що секретується в клітинах кісткової тканини та викликає утворення натрій-фосфат-котранспортера, який діє в клітинах нирок і тонкого кишечника, має гальмівний вплив на синтез 1,25(OH) D. Також на метаболізм вітаміну D впливають деякі лікарські засоби (наприклад, протиепілептичні засоби, глюкокортикоїди та інші) [9-11].

1,25(OH) 2 п підвищує експресію 25-гідроксивітаміну D-24-гідроксилази (CYP24R) - ферменту, який каталізує його подальше перетворення, що призводить до утворення водорозчинної біологічно неактивної кальцитриєнової кислоти, яка виділяється з жовчю.

Усі перераховані компоненти метаболізму вітаміну D та RVD об'єднують в ендокринну систему вітаміну D, функції якої полягають у здатності генерувати біологічні реакції більш ніж у 40 тканинах-мішенях завдяки регуляції RVD транскрипції генів (геномний механізм) і швидких позагеномних реакцій, які здійснюються при взаємодії з RVD, що локалізуються на поверхні низки клітин. Завдяки геномним і позагеномним механізмам D-ендокринна система бере участь у регуляції мінерального гомеостазу (насамперед у рамках кальцій-фосфорного обміну), концентрації електролітів та обміну енергії, пригнічує клітинну проліферацію та індукцію кінцевого диференціювання, інгібує ангіогенез, стимулює синтез інсуліну, пригнічує секрецію реніну та підвищує синтез кателіцидину в макрофагах [4, 12-14].

Внаслідок дефіциту вітаміну D знижується всмоктування кальцію та фосфору в кишечнику, в результаті чого підвищується рівень ПТГ, виникає вторинний гіперпаратиреоз, при якому загальний рівень кальцію в сироватці крові знаходиться в межах норми завдяки мобілізації кальцію $з$ кісткової тканини та підвищеному виведенню фосфору нирками $[11,15,16]$. Опосередковане ПТГ підвищення активності остеокластів викликає зниження загальної мінеральної щільності кісткової тканини, внаслідок чого розвиваються остеопенія й остеопороз $[16,17]$. Фосфатурія, зумовлена вторинним гіперпаратиреозом, призводить до зниження рівня фосфору в сироватці крові, який знаходиться на нижній межі норми або й нижче. Наслідком цього $є$ порушення співвідношення кальцію й фосфору, що викликає дефекти мінералізації скелета [15]. У дітей грудного та переддошкільного віку внаслідок дефіциту вітаміну $D$ розвивається рахіт, який характеризується множинними деформаціями кісток [18]. У дорослих зони росту кісток уже закриті, а тому в кістках скелета міститься достатньо мікроелементів для запобігання деформаціям, тому цей дефект мінералізації та відомий як остеомаляція, часто не діагностується $[3,9]$.

25(OH)D $є$ основною циркулюючою формою вітаміну D 3 періодом напіввиведення із кровотоку 2-3 тижні та вважається найкращим індикатором для його моніторингу [2, 1921]. Для визначення рівня $25(\mathrm{OH}) \mathrm{D}$, який відображав би дефіцит та недостатність вітаміну $D$, було проведено декілька широкомасштабних досліджень.

Так, S.M. Pietras та співавт. (2009) встановили, що лише у пацієнтів із вихідним рівнем 25(OH)D, нижчим за 20 нг/мл, спостерігалося статистично суттєве зниження вмісту ПТГ на тлі терапії вітаміном D (учасники дослідження приймали 50000 МO ергокальциферолу один раз на тиждень протягом двох місяців при одночасному прийомі препаратів кальцію) [22].

M.C. Chapuy (1996), M.K. Thomas (1998), M.F. Holick (2005) повідомили про існування достовірного зворотного зв'язку між рівнями ПТГ і 25(OH)D та довели, що рівень ПТГ починає знижуватися та досягає плато у пацієнтів із вмістом 25(OH)D у сироватці крові між 30 і 40 нг/мл [23, 24]. Ці результати також узгоджуються із пороговим рівнем 25(OH)D для профілактики невертебральних переломів та переломів стегнової кістки, який отримали при проведенні недавнього мета-аналізу подвійних сліпих рандомізованих контрольованих досліджень вітаміну D для перорального прийому [21].

R.P. Heaney (2003) довів, що в жінок у постменопаузальному періоді при підвищенні середнього рівня 25(OH)D у сироватці крові з 20 до 32 нг/мл збільшувалася абсорбція кальцію в кишечнику на 45-65\% [25].

\section{ВИЗНАЧЕННЯ ТА КЛАСИФІКАЦІЯ ДЕФІЦИТУ ВІТАМІНУ D}

Зважаючи на вищезазначені результати досліджень, Інститут медицини (Institute of Medicine) та Комітет ендокринологів зі створення настанов із клінічної практики (Endocrine Practice Guidelines Committee) постановили, що дефіцит вітаміну D у дітей та дорослих - це клінічний синдром, зумовлений низьким рівнем 25(OH)D в сироватці крові (нижчий за 20 нг/мл або 50 нмоль/л). 
Рівень 25(OH)D від 21 до 29 нг/мл (тобто від 50,1 до 74,9 нмоль/л) потрібно розглядати як недостатність вітаміну D.

Достатнім рівнем вітаміну D треба вважати показник 25(OH)D вищий за 30 нг/мл (75 нмоль/л).

Інтоксикація вітаміном D настає при рівні 25(OH)D, вищому за 150 нг/мл (375 нмоль/л) [9].

\section{ГРУПИ РИЗИКУ З РОЗВИТКУ \\ ДЕФІЦИТУ ВІТАМІНУ D. \\ ПРИЧИНИ ДЕФІЦИТУ ВІТАМІНУ D}

Основним джерелом поповнення організму вітаміном D дітей і дорослих $\epsilon$ інсоляція. Небагато харчових продуктів містять або збагачені вітаміном D [15], тому основною причиною дефіциту вітаміну $D \in$ недостатнє перебування людини на сонці.

Кут, під яким промені Сонця досягають поверхні Землі, визначає кількість фотонів ультрафіолетового опромінення спектру В, які може отримати певна територіальна одиниця нашої планети. Цей факт зумовлює низький або неможливий синтез вітаміну D в шкірі взимку або вранці чи у вечірній час доби $[26,27]$.

Меланін $є$ особливо ефективним в абсорбції ультрафіолету, тому пігментація шкіри суттєво пригнічує синтез вітаміну D [15]. Подібно до цього застосування сонцезахисних засобів із чинником захисту 30 зменшує синтез вітаміну D в шкірі більш ніж на 95\% [27]. Цим фактом також можна пояснити й те, що афро-американці, які проживають поблизу екватора (найбільш сонячній частині Землі), мають дефіцит вітаміну D, оскільки здатність їхньої шкіри синтезувати холекальцеферол $\epsilon$ дуже низькою [28]. Тому люди, в яких від природи темна шкіра, забезпечені природним захистом від сонця і для синтезу однакової кількості вітаміну D повинні перебувати на сонці принаймні в 3-5 разів довше, ніж особи зі світлою шкірою [29].

Із віком зменшується кількість 7-дегідрохолестеролу в дермальному шарі шкіри. Люди, старші за 70 років, мають приблизно 25\% 7-дегідрохолестеролу від загальної кількості у молодих, тому в осіб літнього віку спостерігається зниження синтезу холекальциферолу на 75\% [30].

Існує обернений зв'язок між рівнем 25(OH)D

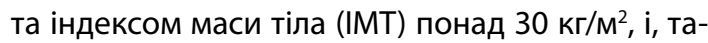
ким чином, ожиріння асоціюється $з$ дефіцитом вітаміну D [31].

Пацієнти із синдромом мальабсорбції жирів та хворі, які перенесли баріатричні операції (хірургічна корекція ожиріння), часто не здатні всмоктувати жиророзчинний вітамін D [15].

У пацієнтів з нефротичним синдромом 25(OH) D виводиться із сечею вітамін D-зв'язаним білком [15].

До групи ризику належать пацієнти, які приймають низку лікарських засобів, включаючи протисудомні, глюкокортикоїди, препарати для лікування ВІЛ/СНІДу, оскільки останні посилюють катаболізм 25(OH)D i 1,25(OH)2D [32].

Хворі на хронічні захворювання, що супроводжуються утворенням гранульом, пацієнти 3 деякими лімфомами та хворі на первинний гіперпаратиреоз також належать до групи підвищеного ризику дефіциту вітаміну $D$, оскільки в них відзначається підвищений рівень метаболізму 25(OH)D до 1,25(OH) 2 D [33, 34].

Метою дослідження було вивчення частоти дефіциту вітаміну D серед населення України та встановлення чинників ризику його розвитку.

\section{МАТЕРІАЛИ ТА МЕТОДИ ДОСЛІДЖЕННЯ}

Обстежено 1575 жителів України, віком 2095 років. Переважну більшість склали жінки (86,3\%). Середній вік останніх склав 58,61 $\pm 0,37$ років, чоловіків - 54,93 $\pm 1,09$ років $(p=0,001)$. Розподіл пацієнтів за віком та регіоном проживання представлений у таблицях 1 та 2.

\begin{tabular}{|c|c|c|}
\hline & & \\
\hline Вікові групи, роки & Кількість обстежених & $\%$ \\
\hline $20-34$ & 117 & 7,4 \\
\hline $35-44$ & 140 & 8,9 \\
\hline $45-59$ & 521 & 33,1 \\
\hline $60-74$ & 670 & 42,5 \\
\hline $75-95$ & 127 & 8,1 \\
\hline
\end{tabular}

Усім обстеженим визначали рівень 25(ОН) D у сироватці крові. Варто зауважити, що до цього дослідження включали лише тих осіб, які не приймали препаратів кальцію та вітаміну $D$ упродовж останніх шести місяців.

ТАБЛИЦЯ 2

\begin{tabular}{|c|c|c|}
\hline Регіон проживання & Кількість обстежених & $\%$ \\
\hline Захід & 209 & 13,3 \\
\hline Схід & 227 & 14,4 \\
\hline Північ & 842 & 53,5 \\
\hline Південь & 50 & 3,2 \\
\hline Центр & 247 & 15,6 \\
\hline
\end{tabular}

Дослідження 25(OH)D проводили за допомогою електрохемілюмінісцентного методу на аналізаторі Elecsys 2010 (Roche Diagnostics, на сьогодні $\epsilon$ найбільш чутливим та дозволяє вимірювати концентрацію досліджуваної речовини в широкому діапазоні з високою точністю (коєфіцієнт варіації до 10\%). 


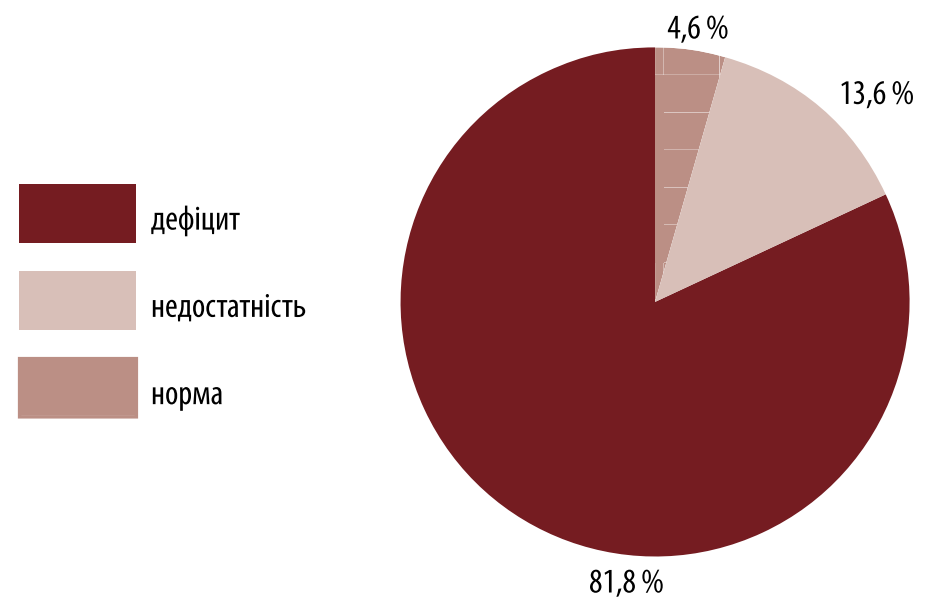

РИС. 2.

ЧАСТОТА ДЕФІЦИТУ ТА НЕДОСТАТНОСТІ ВІТАМІНУ D СЕРЕД НАСЕЛЕННЯ УКРАЇНИ

\section{РЕЗУЛЬТАТИ ДОСЛІДЖЕННЯ ТА ЇХ ОБГОВОРЕННЯ}

Результати проведених досліджень показали, що лише в 4,6\% жителів України рівень 25(OH)D був у межах норми, у 13,6\% із них відзначено не-
Згідно з даними таблиці 3, видно, що в усіх вікових групах середній рівень 25(OH)D - у полі ДВD. Проте спостерігалася його залежність від віку обстежених осіб. Так, достовірно вищий рівень $25(\mathrm{OH}) \mathrm{D}(41,16 \pm 2,53)$ нмоль/л реєструвався у молодих людей порівняно 3 обстеженими віком 35-44 роки $(\mathrm{p}<0,01), 60-74$ роки $(\mathrm{p}<0,05)$ та 75 років і старші $(\mathrm{p}<0,05)$. Найнижчі показники рівня 25(OH)D встановлено в групі 35-44 роки $(30,97 \pm 1,74)$ нмоль/л, що достовірно відрізнялися від вікових груп 45-59 та 60-74 роки $(p<0,05)$.

Достовірно нижчий відсоток ДВD виявлено в молодих осіб порівняно з іншими віковими групами ( $p<0,05-p<0,01)$. Найчастіше ДВD реєСтрувався в осіб, старших за 75 років (84,3\%).

Середній рівень 25(OH)D у жінок склав 33,8 \pm 0,6 нмоль/л та був вірогідно нижчим ( $<<0,001)$ проти середнього рівня цього ж показника у чоловіків (38,9 \pm 1,6 нмоль/л). Таким чином, стать вірогідно впливає на варіабельність показника 25(OH)D в сироватці крові обстежених ( $F=10,87, \mathrm{p}<0,001)$.

ТАБЛИЦЯ 3

\begin{tabular}{|c|c|c|c|c|c|c|}
\hline \multirow[b]{2}{*}{ Статус вітаміну D } & \multicolumn{6}{|c|}{ Вікові групи, роки } \\
\hline & $\begin{array}{c}20-34 \\
(n=117)\end{array}$ & $\begin{array}{c}35-44 \\
(n=140)\end{array}$ & $\begin{array}{c}45-59 \\
(n=521)\end{array}$ & $\begin{array}{c}60-74 \\
(n=670)\end{array}$ & $\begin{array}{c}\text { Старші за } 75 \\
(n=127)\end{array}$ & $\begin{array}{c}\text { Усього } \\
(n=1575)\end{array}$ \\
\hline 25(ОН)D, нмоль/л, $(\mathrm{M} \pm \mathrm{m})$ & $41,16 \pm 2,53^{\# \#}$ & $30,97 \pm 1,74$ & $34,91 \pm 0,91^{\#}$ & $34,08 \pm 0,77^{* \#}$ & $32,65 \pm 1,77^{*}$ & $34,49 \pm 0,53$ \\
\hline Частота недостатності вітаміну D & $20(17,1 \%)$ & $19(13,6 \%)$ & $78(15,0 \%)$ & $83(12,4 \%)$ & $14(11,0 \%)$ & $214(13,6 \%)$ \\
\hline Частота ДВD & $84(71,8 \%)$ & $117(83,6 \%)^{*}$ & $420(80,6 \%)^{*}$ & $561(83,7 \%)^{* *}$ & $107(84,3 \%)^{*}$ & $1289(81,8 \%)$ \\
\hline Частота тяжкого ДВD (< 25 нмоль/л) & $35(29,9 \%)$ & $67(47,9 \%)^{*}$ & $194(37,2 \%)$ & $237(35,4 \%)$ & $51(40,2 \%)$ & $584(37,1 \%)$ \\
\hline
\end{tabular}

* Достовірна різниця рівня 25(ОН)D порівняно 3 віковою групою 20-34 роки $(\mathrm{p}<0,05) .{ }^{* *}$ Достовірна різниця рівня 25(ОН)D порівняно 3 віковою групою 20-34 роки $(\mathrm{p}<0,01) .{ }^{*}$ Достовірна різниця показника 25(ОН)D порівняно 3 віковою групою 35-44 роки $(\mathrm{p}<0,05)$. \# Достовірна різниця показника 25(0H)D порівняно $з$ віковою групою $35-44$ роки $(p<0,01)$

ТАБЛИЦЯ 3.

ЧАСТОТА ДЕФІЦИТУ

BITAMIHУ D У PIЗHИX

ВІКОВИХ ГРУПАХ достатність, а у 81,8\% - дефіцит вітаміну D (ДВD) (рис. 2). Необхідно зазначити, що тяжка форма ДВD (рівень 25(OH)D, нижчий за 25 нмоль/л)
У таблиці 4 показано частоту ДВD серед обстежених залежно від IMT. Виявлено, що рівень 25(OH)D був достовірно нижчий у осіб із дефіци-

\section{ТАБЛИЦЯ 4}

\begin{tabular}{|c|c|c|c|c|c|}
\hline \multirow[b]{2}{*}{ Показник } & \multicolumn{5}{|c|}{ IMT, $\mathrm{kr} / \mathrm{M}^{2}$} \\
\hline & $\begin{array}{c}<18,5 \\
(n=26)\end{array}$ & $\begin{array}{l}18,5-24,9 \\
(n=302)\end{array}$ & $\begin{array}{c}25,0-29,9 \\
(n=398)\end{array}$ & $\begin{array}{c}30,0-34,9 \\
(n=228)\end{array}$ & $\begin{array}{c}>35,0 \\
(n=123)\end{array}$ \\
\hline 25(ОН)D, нмоль/л & $25,5 \pm 4,2$ & $35,6 \pm 1,4$ & $34,9 \pm 1,1$ & $34,2 \pm 1,4$ & $29,8 \pm 1,4$ \\
\hline ДВD, \% & 88,5 & 77,8 & 80,9 & $85,1^{*}$ & $88,8^{* *}$ \\
\hline Тяжкий ДВD, \% & $57,9^{*}$ & 38,1 & 36,9 & 36,0 & 41,4 \\
\hline
\end{tabular}

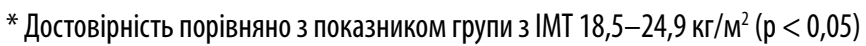

** Достовірність порівняно $з$ показником групи з IMT 18,5-24,9 кг/м² (p<0,01)

ТАБЛИЦЯ 4.

ЧАСТОТА ДЕФІЦИТУ BITAMIHУ D CEPEД

ДОРОСЛОГО НАСЕЛЕННЯ

УКРАЇНИ, ЗАЛЕЖНО ВІД ІМТ $(\mathrm{M} \pm \mathrm{m}), \mathrm{n}=1077$ зустрічалася в 37,3\% обстежених, а в 12,2\% з них рівень 25(OH)D - нижчий за роздільну здатність приладу.

Проведений аналіз рівня 25(OH)D у сироватці крові населення країни в кожній віковій групі наведено в таблиці 3. том маси тіла і склав 25,5 \pm 4,2 нмоль/л, а при IMT понад 35 кг/м² становив 29,8 \pm 1,4 нмоль/л. У цих же групах обстежених реєструвався найвищий відсоток ДВD і тяжкого ДВD. Варто зазначити, що частота ДВD достовірно вищою була в обстежених із IMT 30,0-34,9 кг/M² та найбільш суттєвою в 


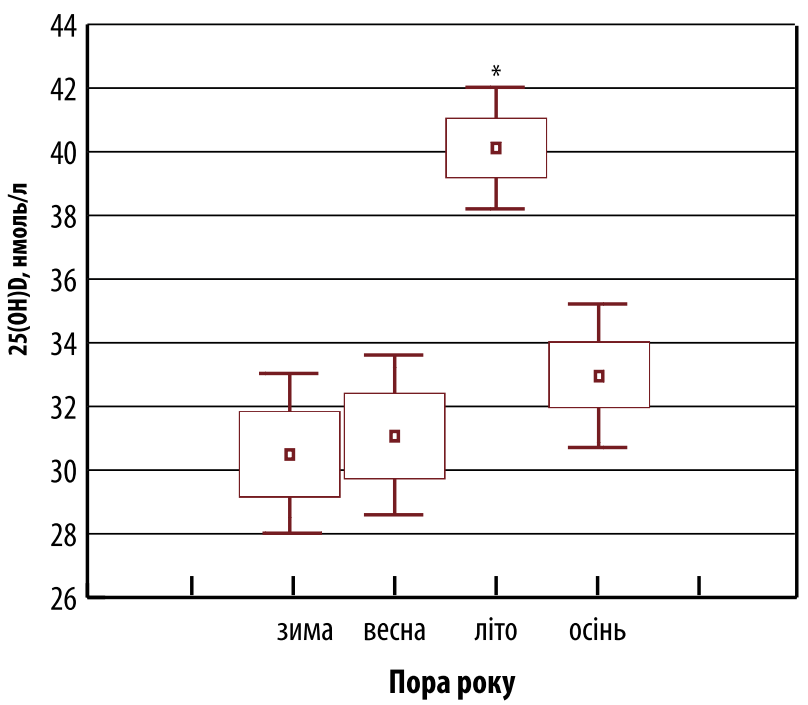

* Вірогідність різниці р <0,0001

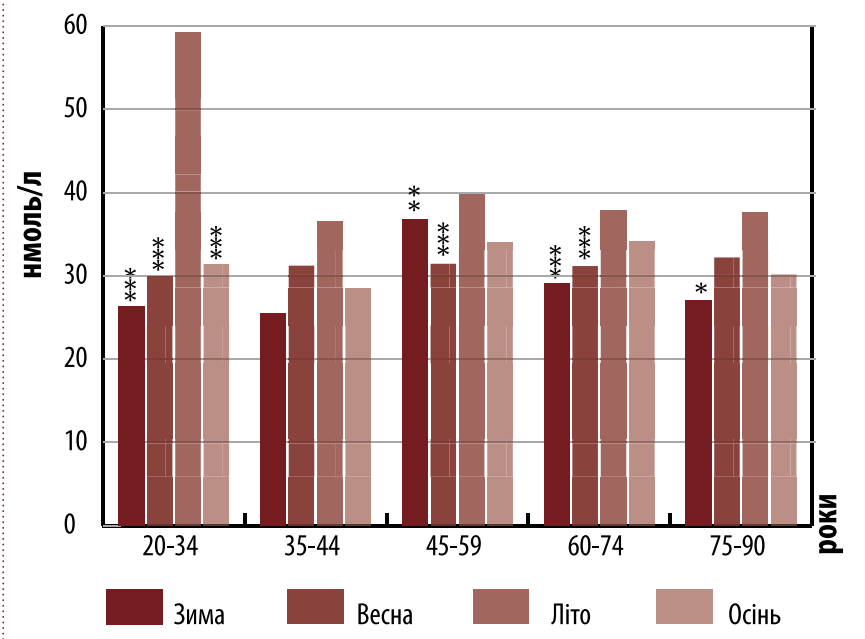

${ }^{*} p<0,05$ порівняно 3 показниками влітку

${ }^{* *} p<0,05$ порівняно $з$ показниками навесні

*** $p<0,001$ порівняно з показниками влітку ЗАЛЕЖНО ВІД ВІКУ ТА ПОРИ РОКУ ОБСТЕЖЕННЯ

у молодих людей (20-34 роки) найвищий рівень 25(OH) D фіксували влітку. Цей показник достовірно відрізнявся в обстежених ( $<<0,001)$ однолітків за іншої пори року (рис. 4).

В осіб літнього віку реєструвалася вірогідна різниця середнього рівня 25(OH)D лише взимку ( $<<0,05)$, показник якого на $30,2 \%$ був нижчим порівняно із середніми даними обстежених влітку.

Аналіз рівня 25(OH)D у людей зрілого віку встановив найнижчі його показники навесні, які були на 29,9\% нижчі за аналогічний рівень влітку ( $p<0,0001)$ та на 17\% - взимку $(\mathrm{p}<0,05)$.

В осіб похилого віку рівень 25(OH)D реєструвався найнижчим взимку і навесні та склав відповідно 29,1 $\pm 1,4$ і 31,2 $\pm 1,6$ нмоль/л проти показників влітку (37,9 \pm 1,2 нмоль/л).

У людей старечого віку середній рівень 25(OH)D був найнижчим взимку і становив 26,9 $\pm 3,3$ нмоль/л та достовірно відрізнявся проти середніх даних рівня 25(OH)D в однолітків обстежених влітку $(37,7 \pm 3,4$ нмоль/л) $(p<0,05)$.

Вивчення середньомісячних коливань рівня 25(OH)D у різних вікових групах населення наведене на рис. 5. На цьому рисунку вказано, що найнижчий рівень 25(OH)D реєструвався в грудні та склав 12,36 \pm 1,23 нмоль/л у людей старечого віку, а в осіб старечого віку він становив 22,34 \pm 2,06 нмоль/л. В обстежених молодого та зрілого віку $25(\mathrm{OH})$ D відповідав 18,53 \pm 5,86 та 18,97 \pm 3,84 нмоль/л відповідно.

Оскільки відомо, що синтез вітаміну D залежить від географічної широти, тому виникла необхідність проведення епідеміологічних досліджень рівня 25(OH)D у населення в різних географічних регіонах країни. За допомогою дисперсійного аналізу встановлено вплив регіону проживання населення на варіабельність показника 25(OH)D у сироватці їхньої крові ( $F=13,16$, p < 0,001). Результати дослідження рівня 25(OH)D наведено на рис. 6.

Як видно з рис. 6, для жителів південного регіону характерні вищі показники 25(OH)D проти обстежених інших регіонів ( $p<0,001)$.

Отже, проведені дослідження виявили ще один чинник, який суттєво впливає на рівень 25(OH)D - це географічне 


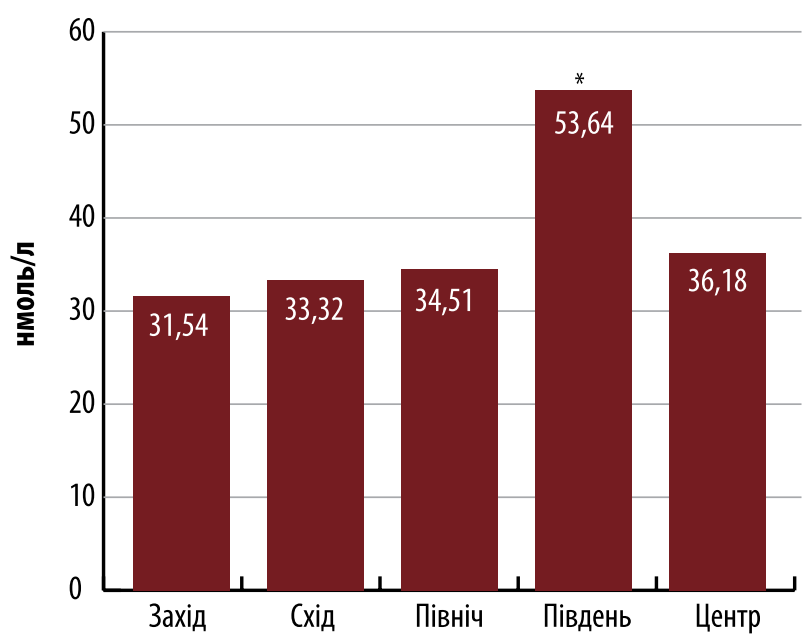

* Достовірність показника 25(ОН)D у жителів південного регіону $\mathrm{p}<0,001$

РИС. 6.

СЕРЕДНІЙ РІВЕНЬ 25(ОН)D У НАСЕЛЕННЯ УКРАЇНИ, ЗАЛЕЖНО ВІД РЕГІОНУ ПРОЖИВАННЯ

\section{ЛITEPATУPA/REFERENCES}

\section{Tangpricha V}

Fortification of orange juice with vitamin D: a novel approach to enhance vitamin D nutritional health / V. Tangpricha, P. Koutkia, S.M. Rieke // Am J Clin Nutr. - 2003. Vol. 77. - P. 1478-1483.

\section{Bikle DD}

Vitamin D: role in skin and hair / In: Feldman D, ed. Vitamin D. Vol 1. 2 nd ed. San Diego, Calif: Elsevier Academic Press. - 2005. - P. 609-630.

3. Holick MF

High Prevalence of Vitamin D Inadequacy and Implications for Health / M.F. Holick // Mayo Clin Proc. - 2006. - Vol. 81 (3). - P. 353-373.

4. Шварц Г.Я.

Витамин D и D-гормон / Г.Я. Шварц // М.: Анахарсис, 2005. - 152 c. Schwartz GJ. Vitamin D and D-hormone / G.J. Schwartz // Moscow: Anaharsis, 2005. $-152 p$.

\section{Holick MF}

The vitamin D content of fortified milk and infant formula/ M.F. Holick, Q. Shao, W. Liu, T. Chen // N Engl J Med. - 1992. - Vol. 326. - P. 1178-1181.

6. Prosser DE

Enzymes involved in the activation and inactivation of vitamin D / D.E. Prosser, G. Jones // Trends in biochemical sciences. - 2004. - Vol. 29. - P. 664-673.

7. Gascon-Barre M

The Vitamin D 25-Hydroxylase / M. Gascon-Barre // Elsevier. - 2005. - Vol. 1.

P. 47-67.

8. Hewison $M$

Extra-renal 25-hydroxyvitamin D3-1alpha-hydroxylase in human health and disease/ M. Hewison, et al. // J Steroid Biochem Mol Biol. - 2007. - Vol. 103. - P. 316-321.

\section{Holick MF}

Evaluation, treatment, and prevention of vitamin D deficiency: an edrocrine society clinical practice / M.F. Holick, N.C. Binkley, H.A. Bischoff-Ferrari et al. // J Clin Endocrinol Metab. - 2011. - Vol.96 (7). - P. 1911-193.

10. Bringhurst TR

Mineral metabolism / In: T.R. Bringhurst, M.B. Demay, P.R. Larson, H.M. Kronenberg, K.S. Polonsky, eds. Williams Textbook of Endocrinology. 10th ed. Philadelphia:WB Saunders. - 2003. - P. 1317-1320. положення території, де проживає населення країни, яке обстежувалося.

\section{ВИСНОВКИ}

1. Епідеміологічні дослідження встановили, що більшість населення України має дефіцит вітаміну D $(81,8 \%)$. Недостатність вітаміну D реєструється у 13,6\% обстежених і лише 4,6\% жителів мають рівень 25(OH)D у сироватці крові в межах норми.

2. Аналіз показників 25(OH)D у кожній віковій групі показав, що достовірно вищий його рівень (41,16 $\pm 2,53$ нмоль/л) реєструвався серед молодих людей порівняно з особами 35-44 роки $(\mathrm{p}<0,01), 60-74$ роки $(\mathrm{p}<0,05)$ та 75 років і старше $(p<0,05)$. Найбільша частка дефіциту вітаміну $D$ діагностувалася в групі осіб, старших за 75 років $(84,3 \%)$.

3. Чинниками розвитку дефіциту вітаміну D серед населення України є:

жіноча стать;

э ожиріння (IMT понад 35 кг/M²);

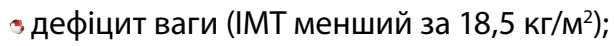

з зимова пора року;

s проживання не в південному регіоні країни.

\section{Heaney RP}

Functional indices of vitamin D status and ramifications of vitamin D deficiency / R.P. Heaney // Am J Clin Nutr. - 2004. - Vol. 80 (6 suppl). - P. 1706-1709.

12. Christakos $\mathrm{S}$

Newinsights into the mechanisms of vitamin D action / S.Christakos, P. Dhawan, Y. Liu, X. Peng, A. Porta // J Cell Biochem. - 2003. - Vol. 88. - P. 695-705.

13. Dusso AS

Vitamin D / A.S. Dusso, A.J. Brown, E. Slatopolsky // Am J Physiol Renal Physiol. 2005. - Vol. 289. - P. 8-28.

14. Bikle DD

VITAMIN D: Newly Discovered Actions Require Reconsideration of Physiologic Requirements/ D. D. Bikle // Trends Endocrinol Metab. - 2010. - Vol. 21(6). - P. 375-384. 15. Holick MF

Vitamin D deficiency / M.F. Holick // N. Engl J Med. - 2007. - Vol. 357. - P. 266 -281. 16. Holick MF

Prevalence of vitamin D inadequacy among postmenopausal North American women receiving osteoporosis therapy / M.F. Holick, E.S. Siris, N. Binkley, M.K. Beard et al. // J Clin Endocrinol Metab. - 2005. - Vol. 90. - P. 3215-3224.

\section{Lips $P$}

The prevalence of vitamin D inadequacy amongst women with osteoporosis: an international epidemiological investigation / P. Lips, D. Hosking, K. Lippuner, J.M. Norquist et al. // J Intern Med. - 2006. - Vol. 260. - P. 245-254.

\section{Gordon CM}

Treatment of hypovitaminosis D in infants and toddlers / C.M. Gordon, A.L. Williams, H.A. Feldman et al. // J Clin Endocrinol Metab. - 2008. - Vol. 93. - P. 2716-2721.

19. De Luca $\mathrm{H}$

Overview of general physiologic features and functions of vitamin D / De Luca H // Am J Clin Nutr. - 2004. - Vol. 80 (6 Suppl). - P. 1689-1696.

20. Holick MF

Vitamin D status: measurement, interpretation and clinical application / M.F. Holick // Ann Epidemiol. - 2009. - Vol. 19. - P. 73-78.

21. Bischoff-Ferrari HA

Benefit-risk assessment of vitamin D supplementation / H.A. Bischoff-Ferrari, A. Shao, B. Dawson-Hughes et al. // Osteoporos Int. - 2010. - Vol. 21. - P. 1121-1132. 


\section{Pietras SM}

Vitamin D2 treatment for vitamin D deficiency and insufficiency for up to 6 years /

S.M. Pietras, B.K. Obayan, M.H. Cai, M.F. Holick // Arch Intern Med. - 2009. -

Vol. 169. - P. 1806-1808.

\section{Holick MF}

The vitamin D epidemic and its health consequences / M.F. Holick // The Journal of nutrition. - 2005 (Suppl. Vitamin D, Sunlight, and Health) - P. 2739-2748.

24. Chapuy MC

Healthy elderly French women living at home have secondary hyperparathyroidism and high bone turnover in winter: EPIDOS Study Group / M.C. Chapuy, A.M. Schott,

P. Garnero, D. Hans et al. // J Clin Endocrinol Metab. - 1996. - Vol.81. - P. 1129-1133.

25. Heaney RP

Human serum 25-hydroxycholecalciferol response to extended oral dosing with cholecalciferol / R.P. Heaney, K.M. Davies, T.C. Chen, M.F. Holick et al. // Am J Clin Nutr. - 2003. - Vol.77. - P. 204-210.

\section{Thacher TD}

Nutritional rickets around the world: causes and future directions / T.D. Thacher, P.R. Fischer, M.A. Strand, J.M. Pettifor // Ann Top Paediatr. - 2006. - Vol. 26. - P. 1-16.

\section{Holick MF}

Vitamin D: a millennium perspective / M.F. Holick // J. Cell Biochem. - 2003. - Vol. 88. - P. 296-307.

28. Matsuoka LY

Sunscreens suppress cutaneous vitamin D3 synthesis / L.Y. Matsuoka, L. Ide, J. Wortsman et al. // J Clin Endocrinol Metab. - 1987. - Vol. 64. - P. 1165-1168.

\section{Hintzpeter B}

Higher prevalence of vitamin D deficiency is associated with immigrant background among children and adolescents in Germany / B. Hintzpeter, C. Scheidt-Nave, M.J. Muller // J Nutr. - 2008 - Vol. 138. - P. 1482-1490.

30. Holik MF

Age, vitamin D, and solar ultraviolet // M.F. Holik, L.Y. Matsuoka, J. Wortsman // Lancet. - 1989. - Vol. 2. - P. 1104-1105.

31. Wortsman J

Decreased bioavailability of vitamin D in obesity / J. Wortsman, L.Y. Matsuoka, T.C. Chen et al. // Am J Clin Nutr. - 2000. - Vol. 72. - P. 690-693.

\section{Zhou C}

Steroid and xenobiotic receptorand vitamin D receptor crosstalk mediates CYP24 expression and drug-induced osteomalacia / C. Zhou, M. Assem, J.C. Tay et al. // J Clin Invest. - 2006. - Vol. 116. - P. 1703-1712.

33. Adams JS

Hypercalcemia caused by granulomaforming disorders / In: Favus M.J. ed. Primer on the metabolic bone diseases and disorders of mineral metabolism. 6th ed. Washington, DC // J.S. Adams, M. Hewison. - 2006. - P. 200-202.

34. Grey A

Vitamin D repletion in patients with primary hyperparathyroidism and coexistent vitamin D insufficiency / A. Grey, J. Lucas, A. Horne, G Gamble // J Clin Endocrinol Metab. - 2005. - Vol. 90. - P. 2122-2126.

\section{ДЕФИЦИТ ВИТАМИНА D СРЕДИ НАСЕЛЕНИЯ УКРАИНЫ И ФАКТОРЫ РИСКА ЕГО РАЗВИТИЯ}

В.В. Поворознюк, д. мед. н., профессор, руководитель отдела клинической физиологии и патологии опорнодвигательного аппарата, ГУ «Институт геронтологии им. Д.Ф. Чеботарева НАМН Украины», Украинский научномедицинский центр проблем остеопороза

\section{Н.И. Балацкая, к. мед. н., ГУ «Институт геронтологии им. Д.Ф. Чеботарева НАМН Украины»}

B статье приведены результаты эпидемиологического исследования частоты дефицита витамина D среди населения Украины. Установлено, что подавляющее большинство жителей страны имеет дефицит витамина D (81,8\%). Наибольшая его доля регистрируется у лиц, старше 75 лет (84,3\%). Факторами риска развития дефицита витамина D среди населения Украины является женский пол, ожирение (ИМт более 35 кг/м²), дефицит веса (ИМТ менее 18,5 кг/M²), зимнее время года и проживание не в южном регионе страны.

Ключевые слова: дефицит витамина D, частота, факторы риска, население Украины.

\section{DEFICIENCY OF VITAMIN D AMONG UKRAINIAN POPULATION: RISK-FACTORS OF DEVELOPMENT}

V.V. Povoroznyuk, MD, professor, head of the Clinical Physiology and Pathology of the Musculoskeletal System Department, D.F. Chebotarev Institute of Gerontology NAMS of Ukraine, Ukrainian Scientific-Medical Osteoporosis Center

\section{N.I. Balatska, PhD, D.F. Chebotarev Institute of Gerontology NAMS of Ukraine}

The article presents the results of epidemiological study the frequency of vitamin D deficiency among Ukraine population. It was shown that majority of examined has got a deficient in vitamin D (81.8\%). 84,3\% of peoples older 75 years old are suffered with vitamin D deficiency. The risk-factors of vitamin D deficiency for Ukrainian population are female gender, obesity (BMl over $35 \mathrm{~kg} / \mathrm{m}^{2}$ ), underweight (BMlless than $18,5 \mathrm{~kg} / \mathrm{m}^{2}$ ), winter season and living notin the southern region of the country.

Key words: vitamin D deficiency, frequency, risk-factors of development, population of Ukraine. 